TI 2017-095/VI

Tinbergen Institute Discussion Paper
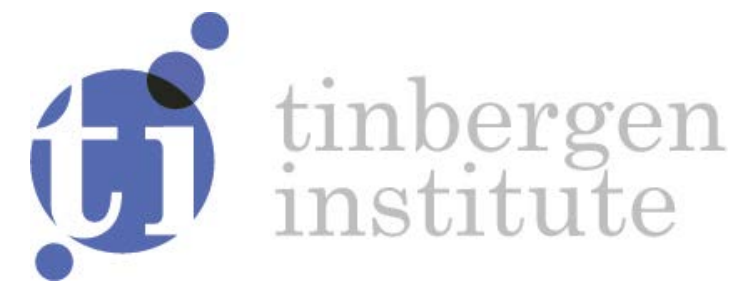

\title{
Contingent Convertibles: Can the Market handle them?
}

Gera Kiewiet $^{1}$

Iman (I.P.P.) van Lelyveld ${ }^{1,2,3}$

Sweder (S.J.G.) van Wijnbergen ${ }^{3,4,5}$

${ }^{1}$ De Nederlandsche Bank, The Netherlands

${ }^{2}$ VU Amsterdam

${ }^{3}$ Tinbergen Institute

${ }^{4}$ University of Amsterdam

${ }^{5}$ CEPR 
Tinbergen Institute is the graduate school and research institute in economics of Erasmus University Rotterdam, the University of Amsterdam and VU University Amsterdam.

Contact: discussionpapers@tinbergen.nl

More TI discussion papers can be downloaded at the Tinbergen Site

Tinbergen Institute has two locations:

Tinbergen Institute Amsterdam

Gustav Mahlerplein 117

1082 MS Amsterdam

The Netherlands

Tel.: +31(0)20 5984580

Tinbergen Institute Rotterdam

Burg. Oudlaan 50

3062 PA Rotterdam

The Netherlands

Tel.: +31(0)10408 8900 


\title{
Contingent Convertibles: Can the Market handle them?
}

\author{
Gera Kiewiet $^{1}$, Iman van Lelyveld ${ }^{1,2,3}$, and Sweder van Wijnbergen ${ }^{3,4,5}$ \\ ${ }^{1}$ De Nederlandsche Bank, ${ }^{2}$ VU University, ${ }^{3}$ Tinbergen Institute, ${ }^{4}$ University of Amsterdam, ${ }^{5}$ CEPR
}

\begin{abstract}
The recent financial crisis has led to the introduction of contingent convertible instruments (CoCos) in the capital framework for banks. Although CoCos can provide benefits, such as automatic recapitalization of troubled banks, their inherent risks raise questions about whether they increase the safety of the banking system. We show that concerns about Cocos in just a single bank can result in the decline of an entire market, with investors apparently unable to distinguish safe from risky bonds. In times of market-panic, investors tend to rely on credit ratings instead of estimating the real risks of missing coupon payments. We provide several recommendations to improve the capital requirements regime for banks.
\end{abstract}

Keywords: Contagion, Contingent Convertible Capital, Systemic Risk

JEL Classification: G01, G21, G32

\footnotetext{
${ }^{1}$ Corresponding author: Gera Kiewiet (g.kiewiet@dnb.nl). We would like to thank DNB colleagues for their input. All remaining errors are ours.
} 


\section{Introduction}

After the 2007-08 Great Financial Crisis, politicians and regulators were adamant to prevent banks relying on tax payers' bailouts in the future. One of the new instruments introduced in the regulatory framework to achieve this were contingent convertible bonds, better known as $\mathrm{CoCos}^{2}$. Banks have started to issue these instruments on a significant scale. Since the introduction of the CRR/CRD IV ${ }^{3}$ in 2014, the CoCo-market has grown rapidly from euro 32 billion at the end of 2013 to euro 157 billion at the end of 2015 (Boermans and van Wijnbergen, 2017). Yet, in spite of this very rapid growth, a seemingly idiosyncratic profit warning, issued by Deutsche Bank (DB) on January $28^{\text {th }} 2016$, followed by a statement by DB intended to reassure markets about DB's ability to continue coupon payments on CoCos on February $8^{\text {th }} 2016$, threw the markets in turmoil. Not just DB's CoCo prices crashed but so did the entire market. If a single bank's profit warning (admittedly a large one) can throw the entire market in a downward spiral, a key question is whether these instruments really make the system safer. This particular market crash is the focus of this paper.

The defining feature of these new CoCo instruments is that they create automatic recapitalization in periods of stress, when shareholders are normally not willing to voluntarily issue new shares. CoCos are in fact subordinated debt that automatically converts into equity (or is written down) when a certain stress related trigger is breached and can therefore absorb losses on a going concern basis. CoCo-holders should thus absorb losses before taxpayers have to step-in. CoCos can help capitalize a bank with minimal disruptions to operations so that these banks do not need capital infusions from the government. Advocates of CoCos see this instrument as a transparent, efficient and less costly resolution mechanism as it improves the equity ratio of a distressed bank at pre-determined terms. Thus, a bank can take advantage of the benefits of debt financing - such as cheaper funding and tax advantages - in normal times while in bad times when failing to honour debt obligations can trigger financial distress - CoCos convert into equity in order to mitigate default risk (Koziol and Lawrenz, 2010).

Although CoCo instruments have obvious benefits, these instruments come with some downside as well. The most widely used argument against the use of

\footnotetext{
2 CoCos are also known as "regulatory hybrid securities" (Squam Lake Working Group, 2009) or "contingent capital certificates" (Flannery, 2009). Earlier proposals are e.g. Harvard Law Association (1991). For an overview of pricing models, see de Spiegeleer et al. (2014).

3 Capital Requirements Regulation (CRR), the capital requirements directive applicable in EU as of 1/1/2014.
} 
CoCos, is that if regulators want to make banks safer, they simply have to require more equity (Admati et al., 2013). Equity is a more reliable buffer while simultaneously reducing the debt overhang. CoCos add complexity to the financial system and put a significant burden on regulators in times of conversion, including legal risks related to conversion. Moreover, Chan and Van Wijnbergen (2014) show that CoCo-conversion may increase the probability of the bank being run on: Conversion can be seen as a negative signal about asset quality, which can result in clients pulling their money out. Besides, CoCos can also create incentives for more risk-taking; if a bank is close to CoCo conversion, the only way to stave off conversion other than by raising new capital is by making a quick profit. As there is a natural trade-off between risk and return, this short-term need leads to gambling for resurrection.

In February 2016, CoCos were put to the test for the first time after DB reported an unexpectedly large 2015 loss on January 28, 20164. On February 10 2016 Bloomberg headlined "Deutsche Bank CoCo Holders See what Regulators Mean by Risk" and quoted an asset manager as saying "They are just too close to the wire" (Gleason et al, 2017). On February $8^{\text {th }}$ DB responded by using its cash available to make CoCo coupon payments and subsequently offered to buy substantial amounts of debt in response to falling prices for DB debt securities. Nevertheless DB CoCo prices crashed by some $10 \%$ against general CoCo indices while CDS spreads spiked and equity prices dropped by substantially more than benchmark equities did (Stevens and van Wijnbergen, 2017).

Although problems started at Deutsche bank, the entire European CoComarket was hit hard. Since the news triggering the volatility was very DB specific, should we conclude that investors were unable to accurately assess the quality of CoCo instruments, leading to unwarranted contagion across all CoCo instruments? This was clearly not what banking supervisors had in mind when accepting the CoCo as part of (AT1) capital requirements. Since design flaws in CoCos might possibly allow problems at one bank to spread to others, regulators may have to reassess the usefulness of these instruments.

To establish whether the market is able to distinguish good quality CoCos from bad quality CoCos, we conduct the first empirical academic study with both market and confidential supervisory data and investigate whether CoCoinstruments present contagion risks. So far, very little empirical research has been done on CoCo instruments. This is partially because the CoCo-market is a relatively immature market that has only recently been established, but also

\footnotetext{
4 A preliminary warning was already issued on January 20th.
} 
because only limited data is publically available to look at the causes of CoCoprice behaviour. We complement Flannery (2014), Avdjiev et al. (2015), and Chan and van Wijnbergen (2014), who like most of the literature looked at conversion triggers and write-down mechanisms but did not pay attention to coupon triggers. But these triggers are by their design the highest and thus will come into play first. Specifically we consider the highest trigger present in CoCo instruments, namely the Maximum Distributable Amount or MDA trigger covering coupon payments rather than conversion of principal. Based on both confidential supervisory data and market data, we will focus on the distance to the MDA-trigger and the effects on CoCo prices. We take into account a wide range of other factors that might influence CoCo prices and market reactions.

The set-up of this paper is straightforward. Section 2 briefly summarizes the capital requirements regime CoCos are part of and provides additional details about the nature and history of CoCos. In Section 3 we discuss related literature while Section 4 covers market developments and defines the main research questions explored in this paper. We outline the empirical methodology employed and describe the data in Section 5. Section 6 presents and discusses the results. Section 7 concludes and offers some takeaways for policy makers.

\section{Capital requirements in financial markets}

\subsection{Capital requirements for banks}

During the crisis, it became clear that sudden changes in asset quality and value can quickly wipe out the capital of a bank (Blundell-Wignall and Atkinson, 2010). In response, the G20 leaders endorsed the Basel III framework in 2010. The endorsement represented a major step towards preventing a future banking crisis (Hannoun, 2010, Hart and Zingales, 2010). Not only the excessive on- and offbalance sheet leverage, but also the gradual erosion of both the level and quality of the capital base were root causes of the collapse of the financial system in 2008. One of the main purposes of the Basel III framework is therefore to not just raise capital requirements but also to increase the quality of capital of banks. Capital should be of sufficient quality to absorb losses when needed.

Regulatory bank capital consists of different items for which capital instruments qualify (see Table 1 in the Appendix for the main features). With the introduction of the Basel III framework, common equity (called CET1: shares, retained earnings, etc.), the highest quality of a bank's capital, is considered the 
most important form of own funds of a bank. CET1 is considered, both in accounting terms and in the capital framework, as equity. The second highest quality of capital is called Additional Tier 1 (AT1) and consists of capital instruments that should be able to absorb losses on a going concern basis, by either a write down or conversion into shares (BCBS, 2011). These instruments are also known as contingent convertibles or CoCos. A last layer of capital in the regulatory framework for banks is called Tier 2 (T2). T2 instruments and items consist of, amongst others, certain types of subordinated debt and general provisions ${ }^{5}$. T2 will be used in gone concern situations in order to shield depositors and senior creditors losses (BCBS, 2011). Similar to AT1 instruments, T2 instruments can be written down or converted into equity, although at a later stage than AT1. Although both AT1 and T2 instruments are considered own funds for prudential purposes, the majority of them will be treated as liabilities for accounting purposes.

In the Basel III regulatory framework for banks capital requirements are set in terms of these three layers of capital (CET1, AT1, T2). Pillar 1 requires minimum risk weighted capital requirements for credit risk, market risk and operational risk. These Pillar 1 requirements consist of a total $8 \%$ capital requirement of which at minimum $4.5 \%$ has to be CET $1,6 \%$ has to be Tier 1 capital, and the remaining $2 \%$ may be filled with Tier 2 capital $^{6}$. Using a higher quality of capital (e.g. using CET1 when AT1 or T2 is allowed, or using AT1 instead of T2 is always permitted).

Pillar 2 addresses the overall capital and liquidity adequacy of a bank in relation to other risks than the risks covered under $\mathrm{P} 1$. In addition, the supervisor performs an annual Supervisory Review and Evaluation Process (SREP) by which the supervisory authority assesses the idiosyncratic risks of a bank, including governance, risk management and stress-scenarios. The supervisor can within certain boundaries ${ }^{7}$ choose to require the quality of P2 capital of a bank in CET1, AT1 or T2.

In addition there is the Combined Buffer Requirement, consisting of several macroeconomic buffers (Countercyclical Buffer, Capital Conservation Buffer) and systemic relevance buffers and consists of CET1 capital. These buffers form a cushion to address macroeconomic and financial stability risks.

\footnotetext{
5 Meeting the criteria set out in 575/2013 Art. $62 \& 63$.

6 CRR (575/2013/EU) Art. 92.

7 There are minimum requirements of at least $56 \%$ of CET1 and $75 \%$ Tier 1 , the supervisor has the flexibility to determine the remaining part of the components (CET1, AT1, T2) of P2 based on their own assessment (EBA, 2014, DNB, 2016).
} 
The capital hierarchy can be seen as an upward cascade. Banks will first have to allocate their capital base to the Pillar 1 requirements, followed by the Pillar 2 requirements and finally to the Combined Buffer Requirement. Hence, if banks have insufficient capital, they will first breach the Combined Buffer Requirement before breaching Pillar 2 and Pillar 1 . The supervisory sanctions also follow this ordering and hence a breach of the Combined Buffer Requirement results in less severe sanctions than when Pillar 2 (or even Pillar 1 ) requirements are not met.

\subsection{Sanctions for not meeting requirements}

Banks have to meet the capital requirements as described in the previous paragraphs at all times. If banks fail to meet the Combined Buffer Requirement, the supervisor can take actions such as requiring divestments, limiting M\&A transactions or limiting dividends, coupon payments and bonuses ${ }^{8}$. In addition to the supervisor's discretionary measures, banks not Figure 1 MDA trigger

meeting their Combined Buffer Requirement have to deal with automatic restrictions on dividend distributions, variable remuneration and coupon payments on AT1 instruments. These automatic restrictions immediately apply once the Maximum Distributable Amount trigger (MDA-trigger) is hit. In

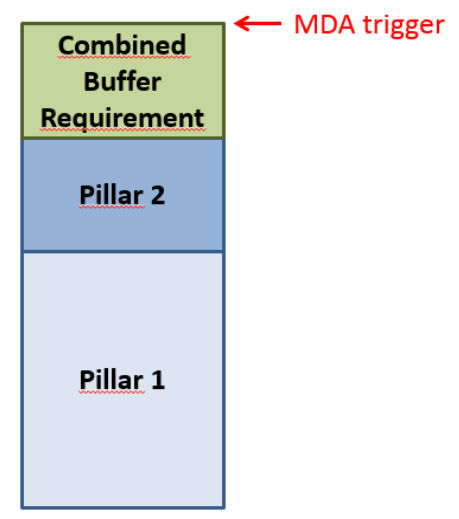
the EU, this trigger (see Figure 2) lies on top of the combined buffer requirement (EBA, 2015). In addition to automatic restrictions based on buffer requirements, banks also need to have sufficient reserves in order to be able to distribute dividends, variable remuneration and coupons. If reserves are restricted or insufficient, or if buffers are breached, banks are automatically restricted in making distributions.

\subsection{CoCo-design}

CoCos are structured with the purpose of providing additional capital to banks in times of financial stress. In order to provide this loss absorbing capacity CoCos have to be able to automatically absorb losses prior to insolvency while simultaneously preventing speculative attacks (Flannery, 2009).

8 CRD (36/2013/EU) Art. 104. 
CoCos have two main design features as can be seen in Figure 5. First, the loss absorption mechanism and, second, the trigger that activates this mechanism (Avdjiev et al. 2013). We will discuss both in turn.

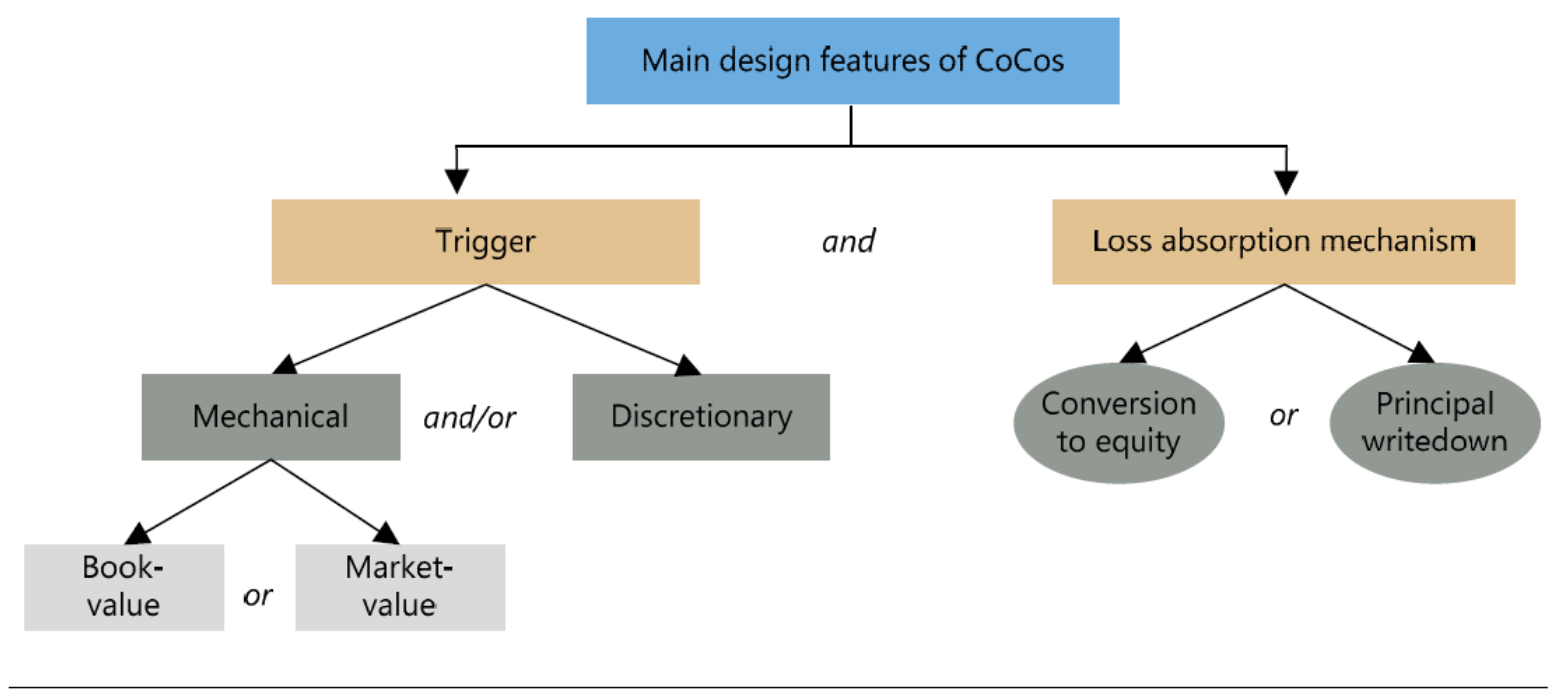

Source: Avdjiev et al. (2013)

CoCos can absorb losses either by converting into common equity or through a principal write down. In both cases the issuing bank's equity is increased and debt is reduced. The conversion rate into equity of a CoCo can be based on the market price of the stock at the time the trigger is breached, a pre-specified price (e.g. stock price at time of issuance), or a combination of both (Avdjiev et al. 2013) ${ }^{9}$. The conversion of CoCos always takes place in full, although the principal write-down of a CoCo can be either partial or in full, as the contract specifies, but that contractually specified percentage is always applied to the entire CoCo. CoCos are always perpetual instruments in order to qualify as Additional Tier 1 capital $^{10}$.

The second key parameter is the conversion trigger point: the point at which the loss absorption mechanism will be activated. The trigger can be activated in either a mechanical or a discretionary way. With a mechanical trigger, the loss absorption mechanism is activated when the capital of the issuing bank has fallen

9 CRR (575/2013/EU) Art. 54 sets a floor (limit) on the rate of conversion. The floor price limits the number of ordinary shares that will be received by CoCo holders on conversion if the current market price is less than the floor price.

10 CRR (575/2013/EU) Art. 54. 
below a minimum risk weighted capital ratio. This is also known as a book-value or accounting trigger (Avdjiev et al., 2013). Under European law, the minimum trigger for conversion is set at $5.125 \%$ of CET1 ratio but may be higher. The higher the conversion trigger, the more expensive it is for a bank to issue the CoCo instrument, as the trigger will be hit earlier. Theoretically, triggers could also be based on market values. Market-value based triggers are set at a minimum ratio of the bank's stock market capitalization to its assets. Flannery (2005, 2009) argues that this market-based view provides a better indicator of a bank's capital adequacy. Regulatory capital relies on accounting-based measures that are slow to respond to new information, whereas market-based indicators could provide a more forward-looking view (Flannery, 2005, 2009). However, as these market value triggers may be difficult to price and could create incentives for stock price manipulation (Avdjiev et al., 2013, Flannery, 2014), they are not widely used in practice. Sundaresan and Wang (2015) argue that using a stock price trigger is problematic as the stock price itself is affected by the possibility of conversion, possibly leading to multiple equilibria for the price.

In the European Union, only the book-value based trigger mechanisms was implemented. European Law ${ }^{11}$ explicitly states that in order to qualify as an Additional Tier 1 instrument for capital purposes, a CoCo instrument should have a mechanical book-value based trigger which is mentioned in the prospectus. In addition to the mechanical triggers, the supervisor has the discretionary power to write-down or force conversion of CoCos. A supervisor can, for instance, require an institution to take measures at an early stage to address capital breaches or other non-compliance with capital regulations ${ }^{12}$. The most likely moment when a supervisor will make use of this discretionary power is when the institution reaches the so called Point of Non-Viability. One of the actions the supervisor can take, is the discretionary write-down of CoCo-instruments. Mandatory early conversion can be used as the last possibility before the point of non-viability to keep capital within the bank. Triggering CoCo-instruments not only increases the amount of CET1 but also prevents the outflow of coupon payments.

As mentioned before, CoCo-instruments have a separate trigger for their coupon payments in addition to the write-down or conversion trigger. Recall from Figure 1 in Section 2.1 that the mechanical coupon trigger is on top of the sum of the Pillar 1, Pillar 2 and Combined Buffer Requirement. The height of the trigger varies depending on the composition of Pillar 2 and the height of the macro-

\footnotetext{
${ }^{11}$ CRR (575/2013/EU) Art. 54.

12 CRD IV (2013/36/EU) Art. $102 \& 104$.
} 
economic buffers. The higher the Pillar 2 requirements and Combined Buffer Requirement, the higher the MDA trigger will be. When the MDA trigger is hit, banks will have to deal with automatic restrictions on coupon payments via a predetermined formula ${ }^{13}$. Hence, the MDA-trigger actually affects CoCo-holders well before the conversion/write down trigger does. Currently the CRR2/CRD5 and BRRD $^{14}$ are being drafted in the EU and in the current draft proposals the MDA trigger will also be hit if banks develop problems with the Total Loss Absorbing Capacity (TLAC) requirements or Minimum requirement for own funds and eligible liabilities (MREL). MREL/TLAC requirements are the requirements banks need to fulfill so that a bank has sufficient capital to write down in resolution. If banks do not meet the MREL/TLAC requirements in the future, the automatic MDA restrictions will be applicable as well. This means that in the future, especially when for instance the MREL/TLAC market has dried up and banks are not able to roll over their MREL/TLAC debt, the MDA trigger is likely to be hit more frequently than under the current regime.

CRD IV (2013/36/EU) Art. 141.

14 Bank Recovery and Resolution Directive (BRRD). 


\section{Review of related literature: benefits and risks of CoCos}

\section{Benefits of CoCos}

CoCos are designed to absorb losses in times of crisis. This can be done first via restrictions on coupon payments due to the MDA trigger, or when problems at a bank are more severe by a write-down or conversion of CoCos in to shareholders equity. CoCos can help capitalize a bank with minimal disruptions to operations so that these banks (hopefully) do not need capital infusions from the government. CoCos work on a going concern basis and can immediately react to capital breaches by conversion or write-down, and could therefore provide an efficient tool for direct capitalization in times of stress. Advocates of CoCos see this instrument as a transparent, efficient and less costly resolution mechanism as they provide an increase in the equity ratio at pre-determined terms when the bank is in distress. Thus, banks can take advantage of the benefits of debt financing such as cheaper funding and possibly tax advantages during good times, while in bad times, when debt obligations impose the risk of financial distress CoCos will convert into equity in order to mitigate default risk (Koziol and Lawrenz, 2010).

According to Calomiris and Herring (2013), the two main reasons why prudential regulation failed to require banks to maintain sufficient capital were distorted measurement of risk and the failure to replenish the equity capital lost during the crisis. Especially in the deepest moment of the 2007/2008 financial crisis, when many banks had depleted their equity, there was no appetite for raising additional equity as extreme dilution for existing shareholders was feared. Institutions that had suffered large losses preferred to wait, hoping for market improvement (Calomiris and Herring, 2013). Calomiris and Herring (2013) state that if banks at that time realized that they would be forced to replace lost capital in a timely fashion, they would have had a greater incentive to manage risk properly and to maintain an adequate equity level. They therefore argue that CoCos, if properly designed, can result in banks implementing strong systems of governance to measure and manage risk and to perform adequate capital planning. Furthermore, in their view, CoCos will encourage timely replacement of lost capital and encourage banks to respond to increased risk with a higher capital base. If banks are troubled but still satisfy the regulatory capital requirements, they may decide to hold out for a government bailout. CoCos are designed to reduce this moral hazard problem by automatic conversion. Furthermore, CoCos 
could help preventing an inaction bias of supervisors. Supervisors are subject to political pressure, which often leads them to prefer to forbear and play for time rather than getting into immediate action to require institutions to issue capital (Flannery (2014), or Chan and van Wijnbergen (2017)). Add to this the fact that supervisors may lack incentives to enforce the spirit of prudential rules as they might be challenged in judicial or administrative proceedings for taking any action that forces an institution to recognize losses, especially when there is hope that losses will be reversed in time (Calomiris and Herring, 2013). Flannery (2014) argues that if contingent capital is inversely related to supervisors' ability to make sure that effective recapitalisation takes place when necessary, CoCos are useful.

More recently Hilscher and Raviv (2014) have shown that CoCos can be beneficial for stabilising financial institutions. They claim that CoCos can eliminate stockholders' incentives to shift risks and can therefore be an effective tool for stabilizing financial institutions. Flannery (2014) goes even further by stating that CoCos represent an under-appreciated device for producing stable financial institutions and a stable financial system. Flannery $(2005,2009)$ also stated that CoCos can be an effective mechanism to exert market discipline as shareholders will have to bear the full cost of their risk-taking decisions rather than relying on government bail-out. Finally, banks issuing CoCos claim that CoCos provide a cheaper alternative to CET1, while simultaneously providing similar loss absorbing capacity as shares.

\section{Risks of CoCos}

Although many have pointed out the above mentioned benefits, some major caveats have also come up. The most widely used counter argument to the use of CoCos is that if regulators want to make banks safer they should simply require them to issue more equity. Admati et al. (2013) in particular state that better equity-capitalized banks suffer fewer distortions in lending decisions and perform better. CoCos certainly add complexity to the financial system and may therefore lead to a more opaque capital structure: a prospectus of a CoCo consists of hundreds of pages, is complex and difficult to understand. Conversion of debt to equity often lead to legal cases and very long legal proceedings that may take several years before being finalized. There has been very little experience with conversion of CoCos to date but it is likely that conversion of CoCos will run into similar legal quagmires. Finally, CoCos may put a high burden on regulators in times of conversion (Chan and van Wijnbergen (2017)). 
Moreover, Chan and Van Wijnbergen (2014) argue that conversion can be seen as a negative signal about asset quality, which can result in clients pulling their money away; if that happens, conversion will actually raise the probability of the converting bank being run. They argue that conversion of CoCos involves wealth transfers between creditors junior to depositors and equity holders who are anyhow always last in line in case of resolution and therefore will not add more comfort towards depositor holders. In addition, they point out that conversion of CoCo-instruments imposes a negative externality on other banks in the system in the likely case of correlated asset returns and may so contribute to systemic risk. This argument echoes earlier research of Kozial and Lawrenz (2010) who similarly state that CoCos can create negative externalities for the economy in the sense that individually rational decisions may have systemically undesirable outcomes. Another concern regarding systemic risk of CoCos stems from the potential destabilizing effect which might occur if large institutional investors are forced to sell their converted bond positions (Financial Times, 2009).

CoCos can also create incentives for more risk-taking. If a bank is close to conversion of CoCos, the only way to increase equity is by either raising new capital or by making additional profits in a very short-time period. As there is a natural trade-off between risk and reward this short-term need for quick profits may result in additional risk-taking. Kozial and Lawrenz (2010) confirm that CoCos can distort risk-taking incentives and induces decision makers to act less prudent depending on the level of financial constraints the bank faces. Chan and van Wijnbergen (2016) systematically investigate the link between risk taking incentives and CoCo design and show that in particular Principal Write Down CoCos lead to even stronger risk taking incentives for bank managers than straight debt.

Given the above-mentioned risks about CoCos, supervisory effectiveness may be hampered. Although mentioned as one of the potential benefits of CoCos, supervisors may actually be even more reluctant to use discretion to convert CoCos as conversion could increase systemic risk (Chan and van Wijnbergen, 2017). Supervisors do also have to take into account, that banks operating close to conversion rates of CoCos may increase risk taking. Similar actions can also be expected for banks acting close to the MDA trigger as banks will try to avoid any negative signals to the market about their profitability. Moreover, CoCos will never prevent failure altogether. Banks can also make other commitments such as accepting deposits and issuing short-term debt. After a CoCo converts into equity the value of a bank's other commitments might still exceed the value of its assets and thus the bank may require additional complementary resolution measures. CoCo conversion is not necessarily sufficient to prevent bankruptcy (Squam Lake 
Working Group, 2009). A last main concern is identified by Prescott (2012) who argues that triggers do not always work efficiently and that thus the market has difficulty in pricing CoCos.

\section{CoCo markets, investors and rating agencies}

The absence of a complete and informative set of credit ratings for CoCos has been a major obstacle for further growth in this market. A lack of ratings, for instance, prevents certain investors - such as pension funds - from investing in these instruments. Many rating agencies face difficulties in rating CoCos. Credit rating agencies are concerned that holders of CoCos will incur losses ahead of shareholders, especially when CoCo conversion/write down triggers are set at a high level (i.e., a trigger above $7.125 \%$ ). This, in combination with the fact that supervisors have the discretion of triggering CoCos on grounds that are usually left opaque in the IPO documents (when a - usually undefined - Point of NonViability is approached), makes rating agencies such as S\&P take a conservative stance in assigning ratings. Based on the recent methodology of S\&P (S\&P, 2014), a CoCo rating is at least two notches below the issuer's own credit rating. For example, if a bank has an " $A$ " rating, the bank's maximum CoCo rating can only be "BBB+" This standard downgrading can be at least partially attributed to the uncertainty the market faces with regard to valuing CoCos, including potential uncertainty about coupon payments. Ultimately such downgrading limits the appeal of this asset class since many institutional investors require a certain minimum rating (e.g. investment grade).

An additional difficulty in pricing CoCos that ratings agencies and investors have to deal with is the divergent legislation across jurisdictions with regard to the coupon related trigger. Although the Basel III rules should ultimately result in convergence of banking rules, the current calculation of the MDA-trigger, the trigger point when banks are automatically subject to restrictions on coupon payments, varies significantly between countries ${ }^{15}$. As can be seen in Figure 1 , the EU MDA-trigger is stacked on top of the combined buffers. Until the end of 2015,

\footnotetext{
15 Currently the relevant triggers differ significantly across jurisdictions. In the US the MDA trigger is placed on top of P1 + buffers (with a separate trigger not including CoCos for Pillar $1+$ Pillar 2). In the UK, the MDA trigger is placed on top of P1 + P2A + buffers but below the PRA buffer (the buffer target set by the supervisor). In Denmark the MDA trigger is on top of Pillar $1+$ the combined buffer requirement while in the Single Supervisory Mechanism (SSM), the MDA trigger is stacked on top of P1 + P2 + combined buffer requirement. In 2017 this will change for SSM countries to P1 + P2R + combined buffer requirements but below P2 Guidance.
} 
however, this stacking order was unclear to the market. More specifically, this meant that in the EU different stakeholders had a different interpretation of the position of the MDA-trigger. In order to clarify the position of the MDA-trigger to the market, the European Banking Authority (EBA) decided to publish an Opinion on the interaction of Pillar 1, Pillar 2, the Combined Buffer Requirement and the restrictions on distributions on $16^{\text {th }}$ December 2015. The EBA-opinion (EBA, 2015) clarified the stacking order of the capital requirements and the position of the MDA-trigger to the market. But the height of the individually determined Pillar 2 buffer requirement was still unknown to the market as supervisors discouraged banks up to half-way 2016 to disclose the required amount of Pillar 2 capital. Hence, investors could only estimate the height of the MDA trigger using publicly available information.

\section{Market developments and main research questions}

The CoCo market in Europe has shown tremendous growth since 2013, once the criteria for CoCos to qualify as AT1 capital became clear with the publication of the legal text of the CRR in early 2013. This growth can be mainly attributed to the finalization of the $\mathrm{CRR}^{16}$ and to the fact that European fiscal authorities made clear to the market that CoCos would be treated as debt for fiscal purposes. Moreover, CoCos catered to the search for yield that intensified as monetary authorities intensified their low interest policies across the Western world. CoCos, almost uniquely at the time, promised stable high coupon payments.

Boermans and van Wijnbergen (2017) document the market development and show that the European Market for CoCos has exploded from a modest euro 31.9 billion EOY 2013 to euro 157 billion at EOY 2015, an annual rate of growth of well over $200 \%$. CoCos are mainly issued by large internationally active banks. Only larger banks, such as Deutsche Bank, UniCredito and ING, have access to the CoCo market. Smaller institutions issue hybrid instruments to a limited extent. Another important demand side aspect is that private investors are generally not allowed to invest in CoCos as market authorities consider the products too complex (AFM, 2015). Although initially the bulk of the demand for CoCos seemed to have come from retail investors in Asia and private banks in Europe (Avdjiev et al. 2013), that pattern has changed over time. Early evidence of banks holding CoCos can probably be traced back to investment banks temporarily holding them

${ }^{16}$ CRR (575/2013/EU) Art. 54. 
while searching for clients to sell them to. Boermans and van Wijnbergen (2017) show that banks did not hold any CoCos on any significant scale anymore late 2015 and were replaced by institutional investors. A similar picture emerges in Hüser et al. (2017). Since banks have to net out their coco holdings from capital for regulatory purposes ${ }^{17}$, banks have no incentive to hold on to this particular asset class.

For shareholders and investors in AT1 instruments it is obviously important to know when breaches will lead to (automatic) restrictions on dividends and coupon payments. Such uncertainty in the market can have important crossmarket price effects (Connolly et al., 2005) and is therefore not conducive to financial stability. At the time of our event, there were two key issues with regard to P2 capital requirements. First, P2 requirements were not published, resulting in uncertainty about the height of this requirement. A second problem concerned the so called stacking order: do the combined buffer requirements come into play only after $\mathrm{P} 2$ buffers have been exhausted or do they come on top as depicted in Figure 2 ? As noted before, reducing this market uncertainty was one of the main reasons for the EBA to publish information about the buffer stacking order in relation to the MDA trigger on December 16th 2015. We will test this formally below, but Figure 3 already suggests that this announcement had no noticeable impact on CoCo bond prices, possibly because the announcement clarified the stacking order but did not change the practice of not publishing the size of the P2 buffer requirements.

However, shortly after the publication of the EBA recommendation, the AT1 market collapsed, arguably triggered by problems at Deutsche Bank (see Figure 3). After an advance warning on January $20^{\text {th }}$, the definitive quarterly profit report was issued on January $28^{\text {th }} 2016$ announcing substantial losses. On February 8, 2016, Deutsche Bank announced that they had sufficient cash available to pay CoCo coupon payments due at the end of April 2016 but in the same statement raised doubts about their ability to pay later coupons. It is this press release that seems to have started the run on the coco market (see Figure 3 below). Prices of other CoCo instruments, other than those issued by $\mathrm{DB}$, also came under pressure. Prices of CoCo-instruments of a wide range of different banks fell precipitously, not just those issued by DB. In fact, the average CoCo price decline was 4.79 on the euro.

${ }_{17}$ CRR (575/2013/EU) Art. 56. 


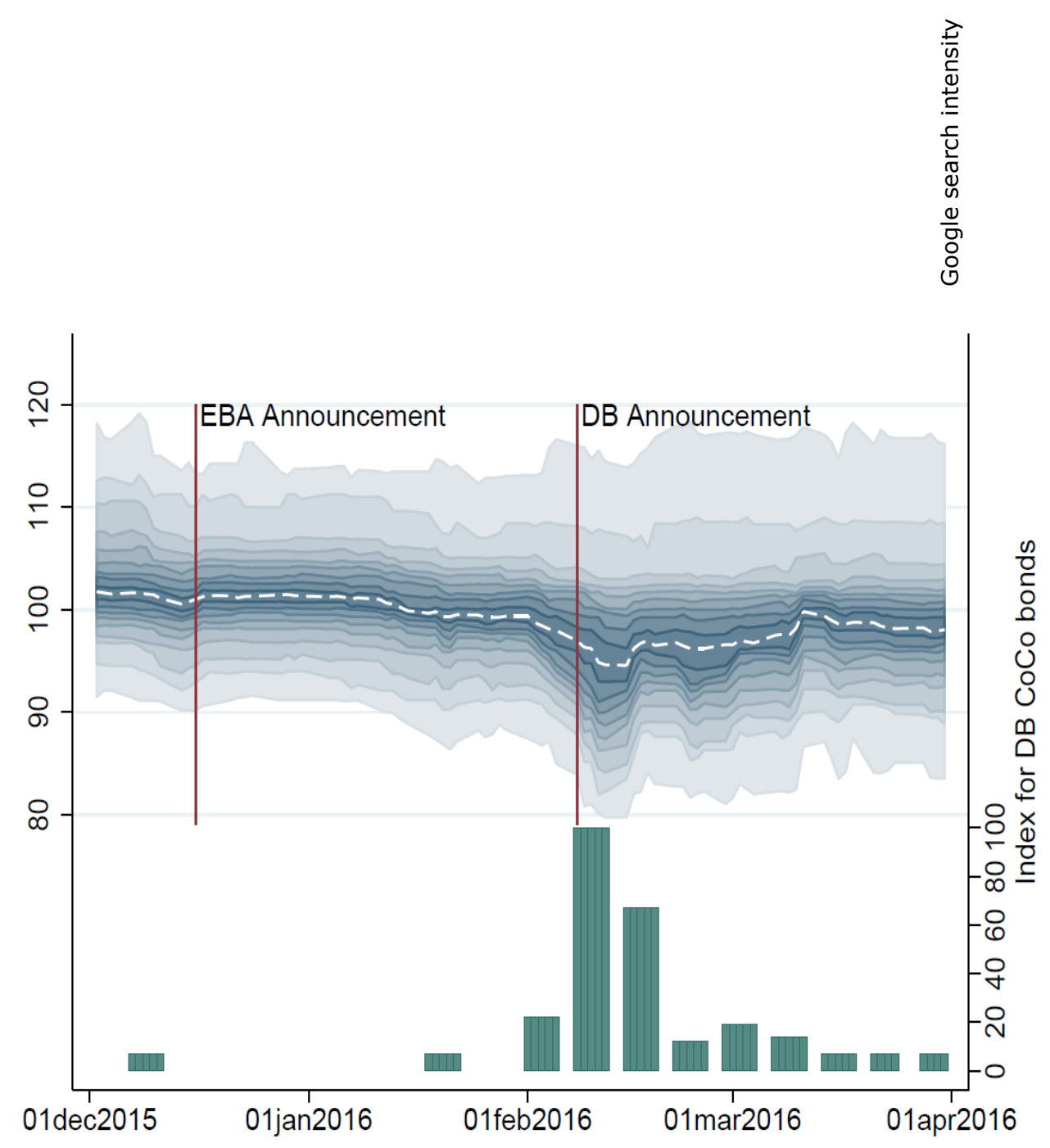

Source: Bloomberg and Google Trends. The announcement days are $16^{\text {th }}$ December 2015 and $8^{\text {th }}$ February 2016 for the EBA and Deutsche Bank announcements, respectively. We plot the distribution of the bond prices in our sample with $5 \%$ increments (excluding the bottom and top $5 \%$ ). The dashed white line shows the median. The bond prices are on the left axis. The bottom plot lists Google searches on "CoCos Deutsche Bank", the most 
popular of similarly phrased searches, indexed to 100 for the most active week (relative hits are listed on the right axis).

Figure 3 also shows information from Google trends: searches for the search term "CoCos Deutsche Bank" exploded after the press release of DB issued on February 8. Figure three also indicates that the entire market crashed, not just the CoCos issued by DB. This collapse of the entire European CoCo-market raises questions about the design and risks of CoCo-instruments and the potential contagion effects present in these instruments.

To test whether the price series shown in Figure 3 indeed show a significant shift, we fit a parsimonious time series model with two time lags and then run structural break tests for unknown break dates for all the available series. The results show that there is some heterogeneity in break dates. The week starting February $8^{\text {th }}$ is clearly the modal week containing about a third of significant break dates in 2016. Combining this with the timing of DB press statement, we choose February $8^{\text {th }}$ as the break date and examine the determinants of the price drops further in the next section.

\section{Research questions}

Why did the prices of CoCos issued by banks that did not face any unexpected financial difficulties also collapse after DB's CoCo prices crashed after DB's profit warning? After all, the main risk that coupon payments might be cancelled is only likely to happen once a bank is operating close to the MDA trigger ${ }^{18}$. CoCos of banks that operate further away from the MDA trigger - that is, have a larger capital cushion between their entire capital base and the point where the MDA trigger kicks in - should have been considered safer with regard to coupon payout certainty than a CoCo of a bank that is close to the MDA trigger point. The larger the distance to the MDA trigger, the less likely coupon restrictions will apply, even if temporary losses force a bank to eat into their capital base. However, trying to assess MDA levels brings two problems to the fore.

First of all, even if the Pillar 2 capital requirements would have been known, the stacking order of the various requirements was not. After the December 2015 publication of the EBA opinion on the stacking order, at least one source of

\footnotetext{
${ }^{18}$ Another possibility of a cancellation of coupons could be that a bank has insufficient distributable items or when the supervisor uses its supervisory discretion. But this is only expected to happen in very rare circumstances.
} 
ambiguity was resolved. So the first question we address is whether that widely publicized letter had any noticeable price impact: investors might have gotten more aware of potential restrictions on coupon payments and the moment these restrictions apply. If there was relevant ambiguity, we would expect a price impact once that ambiguity is removed.

The logical next question involves the remaining uncertainty about the MDA limitation due to the fact that Pillar 2 capital requirements themselves were not public knowledge at the time. Were investors, after the publication of the EBA letter and at the moment that for the first time in such a "safe" bank CoCo history coupon payments were called into question, able to differentiate CoCos that differed in their likelihood to have coupon distributions restricted? Was there at least correlated information available about the MDA trigger? We test that hypothesis using unpublished data on individual banks' position with respect to their MDA triggers. If investors have access to correlated information, the real MDA information should have explanatory power. If investors cannot make the distinction between CoCos that are more likely to be MDA-triggered than CoCos that are not, this should be worrying. It would imply that around an episode such as with Deutsche bank in February 2016, CoCos that should be considered of good quality, and hence be safer, could nevertheless respond negatively. If investors have no way to assess MDA trigger risk, there is a real risk of undue spillovers to CoCos that should be safe (what Ahnert et al. (2017) called "information contagion").

After the recent turbulence in the CoCo market, it should be of substantial interest to supervisors what kind of CoCos have responded more severely to the problems of Deutsche bank. Given the way CoCos are structured, we would expect the prices of CoCos of banks that operate further away from the MDA trigger to have responded less than CoCo prices of banks that operate closer to the MDA trigger, but did they? The problems at Deutsche Bank were the first real test for the relatively young CoCo-market.

\section{Research Methodology}

In this section we describe the research model, the data and the specification of the equations to be estimated. 


\subsection{Research Model}

In assessing the actual probability that automatic restrictions on coupon payments will materialize, the most relevant indicator is the distance to the MDA-trigger. The more capital a bank is holding, the less likely it is that a bank will breach the capital requirements of the combined buffer requirement, activating the automatic trigger. The analyses will therefore first look at whether the market is able to distinguish between CoCos that operate close to the trigger and CoCos that are less likely to be automatically triggered.

Note that until end 2016 the distance to the MDA-trigger was unobservable for market participants. The amount of capital a bank holds is public, but the height of the MDA-trigger is not. However, past research suggest that at least in the US where a CAMELS rating method $^{19}$ is applied by the supervisor, market investors can distill some of this information. (Hirschhorn, 1987). As the Pillar 2 SREP analyses are very similar to the US CAMELS rating method, EU market players might also be aware of this information. Collecting the information might however be costly and time-consuming.

So, although the actual distance to the MDA trigger is most relevant, the market might use other, easier to observe metrics to determine the quality of a CoCo that are correlated to the (distance to) the MDA trigger. As previous research from O'Keefe and Dahl (1996) and Hirtle and Lopez (1999) state, supervisory information might lose its value quickest when a bank faces financial difficulties. As a robustness check, we will therefore also investigate whether investors use ratings as a proxy measure for the distance to the MDA-trigger in order to estimate CoCo risk. Past research by Grier and Katz (1976) and Hand and Wolthausen (1992) shows that there is a relationship between bond ratings and bond price reactions. This study will therefore also look at whether CoCos with a higher rating responded differently to the collapse of the CoCo market than CoCos with a lower rating.

\subsection{Data}

To ensure that the banks in our sample all face similar capital requirements and are subject to similar supervision, we limit our scope to CoCo instruments in the EU Single Supervisory Mechanism (SSM). The CoCos issued in the SSM all have

\footnotetext{
19 The supervisor rates six dimensions of a bank's condition: its Capital adequacy, Asset quality, Management, Earnings, Liquidity and Sensitivity to market risk (CAMELS). A composite CAMELS rating summarizes the supervisor's assessment of overall bank condition. CAMELS ratings reflect a combination of publicly available information and private information produced by bank examiners during for instance on site investigations.
} 
the same legal features in order to qualify as Additional Tier 1 capital. We have obtained the details on all issued CoCos, such as total amount outstanding, height of the coupon and rating from Bloomberg. In total, we include 89 CoCo instruments issued by 33 different banks. The height of the conversion triggers were not available to us. However, since the conversion triggers are usually materially lower than the MDA-trigger ${ }^{20}$, we expect the market to respond to the MDA trigger much earlier.

The confidential supervisory data on capital requirements for the bank (as of $31 / 12 / 2015)$ are downloaded from the database available at De Nederlandsche Bank, the Dutch banking supervisor. The capital requirements consist of the publicly available Pillar 1 requirements, the non-publicly available Pillar 2 requirements and the publicly available Combined Buffer Requirement of the banks in the sample. The capital requirements are usually determined once a year, but can be amended if the supervisor deems this necessary ${ }^{21}$.

With regard to bank specific data, such as the asset size, we take these from the COREP 22 and FINREP ${ }^{23}$ reports that banks submit to the supervisor (as per $31 / 12 / 2015)$. This information can also be derived from the annual reports and from Pillar 3 reports and is publicly available. The credit ratings used are obtained from Bloomberg. We use Fitch ratings as these cover the largest number of rated CoCos (68), in addition, in order to not remove too many CoCos from the sample we included an additional 9 ratings for which Fitch had no rating available, but Moody's had. These Moody's ratings have been rescaled to match the Fitch ratings. The choice of rating agency is not crucial for our results since the different ratings are highly correlated (a correlation of 0,872 ). This results in a total sample of 77 CoCos.

\subsection{Variables used in the analysis}

Our empirical approach is a straightforward event study. As the dependent variable we take the decline in the CoCo price around the Deutsche event, using

\footnotetext{
20 The majority of CoCos have the $51 / 8$ trigger conversion trigger although some instruments have a trigger of around $71 / 8$.

21 For UBS Luxembourg, a subsidiary with nine issues, Barclays PLC France (eight issues), and Danske Bank (two issues), the capital requirements for Pillar 2 are not available. We therefore exclude these banks from our analysis of the relevance of the distance to MDA trigger.

22 Common Reporting Framework (COREP) is the standardized reporting framework issued by the EBA for the Capital Requirements Directive reporting. It covers credit risk, market risk, operational risk, own fund and capital adequacy ratios.

23 Financial reporting (FINREP) is similar to COREP but based on annual report and supervisory figures of the regulatory scope of consolidation.
} 
different windows to distinguish short-term and long-term effects. We include several sensitivity tests; for instance, we first investigate whether it was actually the EBA-opinion that triggered the change in market sentiment.

The market price of CoCos is measured in relation to their face value (i.e., 100 means the CoCo price $\mathrm{p}_{\text {coco }}$ equals the face value of the $\mathrm{CoCo}$ ). The explained variable is the average rate of change in the CoCo price measured over the window used: $d p_{\text {coco. }}$ Our main explanatory variable, $d_{M D A}$, is the difference between the actual amount of Risk Weighted Capital the bank has and the height of the MDA trigger (Pillar $1+$ Pillar $2+\mathrm{CBR}$ ). Recall that the amount of Pillar 2 capital is information that is not publicly available, although some banks provide this information in their investors relations presentations.

The Fitch and (rescaled) Moody's ratings have been transformed to a numerical scale, mapping the highest rating "AAA" to the number 24 and the lowest " $\mathrm{D}$ " to 1.

In addition, we include a comprehensive set of control variables. For instance, we include firm size as larger firms might provide more relevant information. One would also expect that more information is available about the activities of larger firms and that more individuals process and disseminate this information to a broader group of market agents (Anthony and Ramesh, 1992). Moreover, Fama and French (1993) have shown a relationship between firm size and stock returns. Firm size is measured as a bank's total assets (TAs). Another control variable included, is the leverage ratio (Levr). The Basel committee introduced a non-risk based leverage ratio to act as a credible supplementary measure to the risk based capital requirements. The leverage ratio has the intention to restrict the build-up of leverage in the banking sector to avoid destabilizing deleveraging processes that can damage the broader financial system and the economy and to reinforce the risk-based requirements with a simple, non-risk based "backstop" measure. The leverage ratio is measured by dividing the capital measurement ${ }^{24}$ by its exposure measurement ${ }^{25}$ (BCBS, 2014). Banks with higher leverage ratios are generally deemed safer. If this holds, CoCos of banks with better leverage ratios should have reacted less negatively to the Deutsche Bank distress event than banks with lower leverage ratios. Lev (1974) also notes that highly leveraged firms

\footnotetext{
${ }^{24}$ The capital measure for the leverage ratio is the Tier 1 capital of the risk-based capital framework as defined in paragraphs 49 to 96 of the Basel III framework, taking account of the transitional arrangements.

25 The exposure measure for the leverage ratio should generally follow the accounting value, subject to the following: on-balance sheet, non-derivative exposures are included in the exposure measure net of specific provisions or accounting valuation adjustments (e.g., accounting credit valuation adjustments) and netting of loans and deposits is not allowed.
} 
tend to exhibit greater stock return variance. We therefore included the leverage ratio as a control variable.

A third control variable is the cost-to-income-ratio (CTI) of banks. This ratio is calculated by dividing the operating costs by operating income of banks. Pasiours and Kosmidou (2007) suggest that the cost-to-income-ratio shows the costs of running a bank and has a negative relationship with bank performance. Banks which are performing badly are likely to eat into their capital base and are less likely to be able to pay-out coupons.

In order to control for region-specific effects, a fourth control variable distinguishes between banks from the South and the North of Europe ${ }^{26}$ (Region). This dummy is suggested by Black et al. (2016) who find that banking systems of certain countries played unique roles during the crisis. For instance, in the sovereign debt crisis, the largest increase in contributions to systemic risk came from Italian and Spanish banks. This suggests that concerns regarding banks in Southern European countries can have systemic risk implications for the rest of Europe.

A fifth control variable is the Return on Assets (ROA). Flannery $(2005,2009)$ argues that CoCos can be an effective mechanism to exert market discipline as shareholders will have to bear the full cost of their risk taking decisions rather than relying on government bail-outs. However, CoCos can also create incentives for more risk-taking. If a bank is close to CoCo conversion, the only way to increase equity is by either raising new capital, which is difficult in the short run, or by making additional profits in a very short-time period. Gorton and Rosen (1995), for instance, argue that in an unhealthy banking industry entrenched managers are likely to take excessive risk. As there is a natural trade-off between risk and reward, this short-term need for quick profits may result in additional risk-taking. On the one hand a higher Return on Assets could be positive for CoCo holders as this will likely result in more profits (Kwan and Eisenbeis, 1997) and hence a lower chance of breaching the MDA trigger. On the other hand, however, a higher ROA might be an indicator of high risk taking with only upward potential for shareholders (as they can obtain more dividends) risking the fixed coupon payments of CoCo-holders.

The sixth and last control variable is the coverage ratio (Covr)). The coverage ratio is the percentage of specific allowances for non-performing loans over the

\footnotetext{
${ }^{26}$ For the analyses we construct a dummy which is 1 for banks operating in Southern Europe (i.e. France, Greece, Italy and Spain). All other banks are assigned a 0 (i.e., Austria, Belgium, Finland, Germany, Ireland, Luxembourg, and the Netherlands).
} 
amount of non-performing loans. The higher the coverage ratio, the more provisions the bank has had to take to cover for non-performing loans. Note that during our estimation period, the new IFRS9 rules on provisioning against prospective losses were not implemented yet, and provisions could thus only be recognized if loans were actually overdue (90 days or more: "occurred losses"). One interpretation of this variable could be that fewer future losses can be expected for a bank with higher coverage ratios since most of the bad news has already been processed by the market. This can be positive for CoCo-holders as provisions that decrease retained earnings have already been taken and that no additional losses which could result in a breach of the MDA trigger are expected. Note that an alternative causation could be that high provisioning is a sign of bad news still to come.

Taking all this together yields our Equation (1). The model includes both the distance to MDA and Fitch/Moody's ratings as well as the six control variables discussed above. For each time window we also estimate a model where we do not include the Distance to MDA and Rating jointly but separately ${ }^{27}$.

$$
d p_{\text {CoCo }}=\alpha+\beta_{1} d_{M D A}+\beta_{2} \text { Rating }+\beta_{3} \text { ROA }+\beta_{4} \text { Levr }+\beta_{5} \text { CTI }+\beta_{6} \text { Region }+\beta_{7} \text { Covr }+\varepsilon
$$

\section{Empirical analysis}

We first present an overview of the main descriptive statistics of the variables used in the regression analyses (Table 1 ). The distance to the MDA trigger was on average $3.66 \%$ of risk weighted capital. This means that banks had a capital ratio that was on average 3.66 percentage points (366 basis points) above the required capital ratio at which coupons would be automatically restricted. Note that the standard deviation is high, almost as large as the mean value.

The average CoCo rating in the sample is 14.22, which is between BB+ and BBB. The ROA was on average $0.35 \%$, slightly above the average of the largest 154 European banks as published by the $\mathrm{EBA}^{28}$. The leverage ratio is on average $4.81 \%$, well above the minimum $3 \%$ requirement. Note that in line with what is customary in banking regulation, we define the leverage ratio as equity over

\footnotetext{
27 The coverage of the explanatory variables differs and we thus cannot exclude the possibility that differential data availability might have an impact on our results.

28 EU Banking risk dashboard: https://www.eba.europa.eu/-/eba-updated-risk-dashboard-shows-eu-bankshave-further-increased-their-capital-ratios-in-q4-2015.
} 
assets, so banks with a higher ratio are less risky. The cost-to-income ratio in the dataset is on average $54.78 \%$, which is below the EU average of around $60 \%$. The average of total assets is around 521 billion euro. Finally the coverage ratio is on average $44.1 \%$ similar to the $43.8 \%$ in the EBA banking risk dashboard ${ }^{28}$.

Table 1 below shows the correlation matrix of the explanatory variables. The majority of correlations are far below 0.8 , with the exception of the correlation between the coverage ratio and the CTI (cost ratio) which equals 0.77 . The matrix suggests there is no multicollinearity problem.

Table 1 Means, standard deviations and correlations

\begin{tabular}{lcccccccc}
\hline Variables & $\begin{array}{l}\text { Distance } \\
\text { to } \\
\text { MDA }\end{array}$ & $\begin{array}{l}\text { Rating } \\
\text { (Fitch) }\end{array}$ & RoA & $\begin{array}{l}\text { Leverage } \\
\text { ratio }\end{array}$ & $\begin{array}{l}\text { Cost-to- } \\
\text { Income } \\
\text { ratio }\end{array}$ & South & Assets & $\begin{array}{l}\text { Coverage } \\
\text { ratio }\end{array}$ \\
\hline Mean & 3.66 & 14.22 & 0.35 & 4.81 & 54.78 & 0.46 & 521.62 & 44.10 \\
Standard Deviation & 3.05 & 1.56 & 0.54 & 2.11 & 22.50 & 0.50 & 571.08 & 17.02 \\
\hline Distance to MDA & 1.00 & & & & & & & \\
Rating (Fitch) & 0.53 & 1.00 & & & & & & \\
RoA & 0.07 & 0.17 & 1.00 & & & & & \\
Leverage ratio & 0.09 & -0.21 & 0.21 & 1.00 & & & & \\
Cost-to-Income ratio & -0.39 & -0.14 & -0.12 & 0.41 & 1.00 & & & \\
South & -0.25 & -0.21 & -0.14 & -0.36 & -0.20 & 1.00 & & \\
Assets & -0.44 & -0.20 & -0.05 & -0.09 & 0.46 & 0.24 & 1.00 & \\
Coverage ratio & -0.45 & -0.05 & 0.27 & 0.45 & 0.77 & -0.04 & 0.56 & 1.00 \\
\hline
\end{tabular}

\section{Regression results}

The first event we investigate is the release of the EBA opinion on $16^{\text {th }}$ December 2015. The intent of releasing this opinion was to reduce uncertainty in the market regarding the height of the MDA trigger by publishing the rules governing the stacking order of the various capital components. As such we would expect some market reaction. But Figure 3 already suggests that the distribution of CoCo prices did not show any appreciable movement over any window centered around the date of the EBA letter. This can indicate that the market already knew the position of the MDA trigger before the publication date, that the market needed time to absorb the new information, or that it did not materially reduce the uncertainty. After all knowing the stacking order does not help much since the required P2 buffers were still unknown. To investigate whether this hides cross-sectional movement within the distribution, we regress Equations 1 through 3, shown in 
Table 2. We use 1 week, 2 week and 1 month windows. We do not extend the window size beyond one month on each side so as to avoid overlap with the subsequent Deutsche Bank event.

Table 2 EBA opinion event regressions

\begin{tabular}{|c|c|c|c|c|c|c|c|c|c|}
\hline \multirow[b]{2}{*}{ Variables } & \multicolumn{3}{|c|}{1 week window } & \multicolumn{3}{|c|}{2 week window } & \multicolumn{3}{|c|}{1 month window } \\
\hline & (1) & (2) & (3) & (4) & (5) & (6) & (7) & (8) & (9) \\
\hline \multirow[t]{2}{*}{ Distance to MDA } & -0.10 & -0.06 & & 0.13 & 0.08 & & 0.12 & $0.12^{*}$ & \\
\hline & $(0.084)$ & $(0.147)$ & & $(0.076)$ & $(0.102)$ & & $(0.080)$ & $(0.019)$ & \\
\hline \multirow[t]{2}{*}{ Rating } & 0.05 & & 0.03 & -0.04 & & -0.01 & 0.09 & & 0.07 \\
\hline & $(0.577)$ & & $(0.671)$ & $(0.724)$ & & $(0.950)$ & $(0.443)$ & & $(0.406)$ \\
\hline \multirow[t]{2}{*}{ Leverage ratio } & $0.23^{*}$ & 0.09 & $0.19^{*}$ & $-0.27^{*}$ & -0.10 & -0.22 & $-0.28 *$ & $-0.18^{*}$ & -0.21 \\
\hline & $(0.024)$ & $(0.233)$ & $(0.049)$ & $(0.030)$ & $(0.297)$ & $(0.058)$ & $(0.020)$ & $(0.048)$ & $(0.075)$ \\
\hline \multirow[t]{2}{*}{ Assets } & 0.00 & -0.00 & 0.00 & -0.00 & 0.00 & -0.00 & -0.00 & -0.00 & -0.00 \\
\hline & $(0.493)$ & $(0.706)$ & $(0.905)$ & $(0.402)$ & $(0.760)$ & $(0.718)$ & $(0.221)$ & $(0.782)$ & $(0.776)$ \\
\hline \multirow[t]{2}{*}{ RoA } & $-1.09^{* *}$ & $-0.72^{* *}$ & $-1.05^{* *}$ & $1.11^{* *}$ & $0.75^{*}$ & $1.06^{* *}$ & $1.32^{* *}$ & $0.91^{* *}$ & $1.24^{* *}$ \\
\hline & $(0.000)$ & $(0.004)$ & $(0.000)$ & $(0.002)$ & $(0.011)$ & $(0.002)$ & $(0.000)$ & $(0.002)$ & $(0.000)$ \\
\hline \multirow[t]{2}{*}{ Cost-to-Income ratio } & -0.02 & -0.01 & -0.02 & $0.03^{*}$ & 0.01 & 0.02 & 0.02 & 0.01 & 0.02 \\
\hline & $(0.050)$ & $(0.294)$ & $(0.087)$ & $(0.049)$ & $(0.236)$ & $(0.087)$ & $(0.095)$ & $(0.389)$ & $(0.163)$ \\
\hline \multirow[t]{2}{*}{ Coverage ratio } & -0.03 & -0.01 & 0.01 & 0.04 & 0.01 & -0.00 & 0.04 & 0.02 & -0.01 \\
\hline & $(0.274)$ & $(0.745)$ & $(0.700)$ & $(0.200)$ & $(0.684)$ & $(0.904)$ & $(0.120)$ & $(0.346)$ & $(0.723)$ \\
\hline \multirow[t]{2}{*}{ South } & 0.49 & 0.29 & 0.22 & -0.61 & -0.34 & -0.29 & $-1.00^{*}$ & $-0.83^{*}$ & -0.52 \\
\hline & $(0.133)$ & $(0.289)$ & $(0.409)$ & $(0.124)$ & $(0.297)$ & $(0.364)$ & $(0.010)$ & $(0.011)$ & $(0.118)$ \\
\hline \multirow[t]{2}{*}{ Constant } & 1.56 & 1.36 & 0.07 & -2.41 & -1.82 & -0.71 & $-4.29 *$ & -1.86 & -1.78 \\
\hline & $(0.388)$ & $(0.178)$ & $(0.965)$ & $(0.269)$ & $(0.127)$ & $(0.720)$ & $(0.044)$ & $(0.116)$ & $(0.380)$ \\
\hline Observations & 56 & 68 & 67 & 56 & 68 & 67 & 56 & 68 & 67 \\
\hline Adjusted R-squared & 0.259 & 0.149 & 0.184 & 0.215 & 0.123 & 0.137 & 0.370 & 0.306 & 0.235 \\
\hline
\end{tabular}

We do not find very strong effects of the EBA letter at a 5\% level or lower except for one of the three specifications within the 1 month window. To the extent that a downward shift occurred it was bigger in the South and smaller for banks with a high ROA (Equation 7)). The distance to the MDA trigger only shows up significantly in equation (8) but the variable becomes insignificant if the Ratings variable is included also. In the short run (i.e., the 1 week window, columns 1-3), we see that bond prices of banks with lower leverage (higher leverage ratio), increase somewhat. Prices of more profitable banks, drop a little. Possibly there is a risk-return trade off at play here. In the longer run, we see that the leverage ratio and the return on assets effects are reversed. Overall the conclusion seems to be that the EBA letter clarifying the stacking order of the various capital components did not have a significant impact on market prices. 
Regression results around Deutsche Bank event

Next we turn to an investigation of the Deutsche Bank event on February 8, 2016. As discussed in the previous section, this date seems to be a good choice for a common break date. We again show the same set of three Equations for three time windows. In contrast to the EBA regressions, we are not constrained by subsequent events and hence can use wider windows for the longer horizons. The models explain a significant portion of the variation (with adjusted $\mathrm{R}^{2}$ of between almost 30\% and 70\%). The larger the window, the higher the explained variation.

Table 3 Deutsche Bank event regressions

\begin{tabular}{|c|c|c|c|c|c|c|c|c|c|}
\hline \multirow[b]{2}{*}{ Variables } & \multicolumn{3}{|c|}{1 week window } & \multicolumn{3}{|c|}{2 week window } & \multicolumn{3}{|c|}{3 month window } \\
\hline & (1) & $(2)$ & (3) & (4) & $(5)$ & (6) & $(7)$ & (8) & (9) \\
\hline \multirow{2}{*}{ Distance to MDA } & -0.13 & 0.04 & & $-0.42^{* *}$ & -0.08 & & -0.22 & 0.09 & \\
\hline & $(0.369)$ & $(0.802)$ & & $(0.000)$ & $(0.590)$ & & $(0.077)$ & $(0.569)$ & \\
\hline \multirow{2}{*}{ Rating } & $0.93^{* *}$ & & $0.84^{* *}$ & $1.58^{* *}$ & & $1.14^{* *}$ & $1.54^{* *}$ & & $1.23^{* *}$ \\
\hline & $(0.000)$ & & $(0.000)$ & $(0.000)$ & & $(0.000)$ & $(0.000)$ & & $(0.000)$ \\
\hline \multirow[t]{2}{*}{ Leverage ratio } & 0.39 & -0.48 & 0.44 & $0.60^{* *}$ & -0.46 & $0.64^{* *}$ & $0.54^{*}$ & -0.43 & $0.62^{* *}$ \\
\hline & $(0.137)$ & $(0.066)$ & $(0.059)$ & $(0.004)$ & $(0.101)$ & $(0.002)$ & $(0.015)$ & $(0.154)$ & $(0.004)$ \\
\hline \multirow[t]{2}{*}{ Assets } & -0.00 & $-0.00^{*}$ & -0.00 & $-0.00^{* *}$ & $-0.00^{* *}$ & $-0.00^{* *}$ & $-0.00^{* *}$ & $-0.00^{* *}$ & $-0.00^{* *}$ \\
\hline & $(0.605)$ & $(0.014)$ & $(0.961)$ & $(0.000)$ & $(0.001)$ & $(0.002)$ & $(0.000)$ & $(0.005)$ & $(0.001)$ \\
\hline \multirow[t]{2}{*}{ RoA } & $-2.39^{* *}$ & -0.98 & $-2.51^{* *}$ & $-3.44^{* *}$ & -1.59 & $-3.46^{* *}$ & $-3.82^{* *}$ & -1.61 & $-3.82^{* *}$ \\
\hline & $(0.002)$ & $(0.217)$ & $(0.000)$ & $(0.000)$ & $(0.070)$ & $(0.000)$ & $(0.000)$ & $(0.084)$ & $(0.000)$ \\
\hline \multirow[t]{2}{*}{ Cost-to-Income ratio } & $-0.09^{* *}$ & $-0.07^{*}$ & $-0.08^{* *}$ & $-0.12^{* *}$ & $-0.09^{*}$ & $-0.08 * *$ & $-0.12^{* *}$ & $-0.09^{*}$ & $-0.09^{* *}$ \\
\hline & $(0.003)$ & $(0.045)$ & $(0.002)$ & $(0.000)$ & $(0.011)$ & $(0.000)$ & $(0.000)$ & $(0.014)$ & $(0.000)$ \\
\hline \multirow[t]{2}{*}{ Coverage ratio } & -0.00 & 0.04 & -0.00 & $0.12^{* *}$ & 0.09 & $0.13^{* *}$ & $0.19^{* *}$ & 0.11 & $0.16^{* *}$ \\
\hline & $(0.985)$ & $(0.471)$ & $(0.930)$ & $(0.009)$ & $(0.139)$ & $(0.002)$ & $(0.000)$ & $(0.092)$ & $(0.000)$ \\
\hline \multirow[t]{2}{*}{ South } & -1.08 & $-2.64^{* *}$ & -0.78 & $-1.44^{*}$ & $-2.47^{*}$ & -0.84 & $-2.63^{* *}$ & $-3.15^{* *}$ & $-1.89 * *$ \\
\hline & $(0.164)$ & $(0.003)$ & $(0.210)$ & $(0.018)$ & $(0.010)$ & $(0.128)$ & $(0.000)$ & $(0.002)$ & $(0.001)$ \\
\hline \multirow[t]{2}{*}{ Constant } & $-13.09^{* *}$ & 2.45 & $-13.68^{* *}$ & $-23.91^{* *}$ & 2.96 & $-23.19^{* *}$ & $-26.01^{* *}$ & 1.54 & $-24.14^{* *}$ \\
\hline & $(0.006)$ & $(0.458)$ & $(0.001)$ & $(0.000)$ & $(0.412)$ & $(0.000)$ & $(0.000)$ & $(0.688)$ & $(0.000)$ \\
\hline Observations & 58 & 70 & 69 & 58 & 70 & 69 & 58 & 70 & 69 \\
\hline Adjusted R-squared & 0.399 & 0.280 & 0.437 & 0.714 & 0.286 & 0.656 & 0.716 & 0.288 & 0.700 \\
\hline
\end{tabular}

Now we do find a significant downward shift in all equations except the ones where the Ratings variable is omitted, so we confirm the time series evidence of a significant market wide downward shift after the DB announcement. And the downward shift is larger going from a one week window to a two week window but does not seem to increase further: the constant terms in the two week regressions is not significantly different from the term estimated in the 3 months window regressions. Apparently the impact stabilized after about two weeks.

A key finding is that the distance to the MDA-trigger is not significantly related to the change in CoCo-prices for any of the windows. This strongly indicates that the 
market is not able to distinguish between CoCos that operate close to the MDAtrigger and those that are safer with regard to coupon payments. And although the distance to the MDA trigger is not significant, the ratings are: regardless of the chosen window, the market seems to rely heavily on public ratings in pricing CoCos with highly rated CoCos decreasing less in price around the event date.

As for the other control variables: these are all as one would expect. Total assets are negatively related with the change in price. One potential explanation might be that larger banks are more in the spotlight, were seen as a safe haven and that investors therefore are less forgiving if a large bank such as for instance Deutsche Bank encounters problems in paying coupons.

In addition, for all windows, CoCos of banks with a higher ROA show larger negative price reactions. This may seem puzzling at first sight but could indicate that a higher ROA is seen as an indicator of more risk taking; with upward potential for shareholders but putting the fixed coupon payments of CoCo-holders at risk. Gorton and Rosen (1995), for instance, argue that in an unhealthy banking industry managers can be expected to take on excessive risk.

The cost-to-income ratio is also negatively related to the dependent variable, meaning that a one standard deviation higher cost to income ratio of the bank led to a 2 percentage point larger drop in a CoCo-prices. These findings are in line with the research of Pasiours and Kosmidou (2007), who argue that the cost-toincome ratio is an accurate measure of the costs of running a bank and hence has a negative relationship with bank performance. Bad performers are likely to eatinto their capital base and are less likely to be able to pay-out coupons which will have a negative impact on CoCo-prices.

Over the longer horizon, the coverage ratio is significantly positive. The higher the coverage ratio, the more provisions have already been taken in order to cover for the non-performing loans. Arguably this is a positive sign for CoCo-holders as retained earnings reducing provisions have already been taken and thus fewer additional losses, which could result in a breach of the MDA trigger, are to be expected.

Finally, the geographical location of the bank is also significantly correlated with the change in CoCo prices. CoCos issued by banks in Southern Europe have gone down more than CoCos issued by banks from Northern Europe reflecting market and institutional circumstances not captured by our other regressors.

Note that we have used 71 out of the 89 CoCos floated in the SSM. The total number of rated CoCos were 77, but 6 CoCos had to be left out as a result of 
missing other data points. Some CoCos that were not included in the analyses of the MDA-trigger, are incorporated in the analyses of Ratings, whereas other CoCos that were included in the Ratings analyses were not available in the MDA-analyses. Of the 89 CoCos available in the SSM only 50 CoCos had both all the capital requirements and control variable data available as well as a rating. In order to verify whether the results of the regression analyses would be different if all analyses would be done with these 50 CoCos only, we also ran the regressions with the sample of 50 only, with qualitatively similar results (not shown).

\section{Conclusions}

We use the recent turmoil after a profit warning at Deutsche Bank (DB) to assess whether markets can adequately price in the riskiness of Cocos: can the market handle these relatively new hybrid debt instruments? After a profit warning late January 2016 and a clarification, or at least a press release intended as such, issued by DB February 8, DB CoCo prices crashed; but so did the entire CoCo market, although to a somewhat lesser extent. Based on a unique dataset we are the first academic study that has shown with market evidence from around the dates the DB episode played itself out that the market is not able to distinguish between the riskiness of different CoCos. Moreover, while the academic literature has focused exclusively on conversion triggers, we are also the first to focus on the higher trigger embedded in CoCos: the MDA trigger. MDA stands for the Maximum Distributable Amount and the distance to this trigger indicates the likelihood that coupon payments are at risk.

The problems at Deutsche Bank resulted in an average decrease of CoCo prices of 4.79 cents to the euro for the entire EU CoCo market; the entire market thus reacted instantaneously to problems at one single bank. Of course this could reflect that the banks all had highly correlated assets, but this is a very unlikely explanation given the diversity of the banks included in our sample. An alternative explanation could be widely spread cross-holdings of banks of each other's CoCos, but this we know not to be the case (cf Hüser et al. (2017) and Boermans and van Wijnbergen (2017)). This is not surprising as the Basel 3 regulation highly discourages banks to purchase each other's CoCo-instruments, such investments effectively carry a $100 \%$ capital requirement.

So why did investors sell off their investments in CoCo-instruments at different banks after a profit warning issued by just one bank? A more likely 
explanation is that market participants realized that CoCos might be riskier than previously assumed, and in particular that they previously underestimated the likelihood of coupon payout restrictions starting to bite. The apparent vulnerability of these relatively new instruments to waves of panic is more likely related to the opaqueness still surrounding key trigger mechanisms embedded in them, and that has therefore been the focus of this paper.

An EBA-opinion issued about a month before the DB scare started attempted to shed more light on the regulatory rules CoCos are subject to. In particular the EBA clarified the stacking order in which various capital components needed to be applied to assess the distance to the trigger on coupon payments. But this information was apparently not enough to significantly affect differential CoCo prices: we show in this paper that the EBA publication did not meet with any significant price response. After the EBA publication, investors were still not able to distinguish between CoCos that were operating further away or closer to the MDA-trigger when problems occurred at Deutsche Bank. This means that the market itself was not able to distinguish CoCos that were safer with regard to coupon payments than CoCos that were not. Hence we focus on the remaining source of uncertainty: critical capital components (the P2 buffers) were until very recently not published, so markets could still not adequately assess the distance to MDA triggers.

We show, using confidential data on the distance to MDA triggers, that the price response to the DB turmoil was unrelated to the issuing bank's actual distance to its MDA trigger. Instead the market seemed to have relied on prior ratings that were assigned to these instruments. CoCos with higher ratings reacted with a lower decrease in price around the problems of Deutsche Bank than CoCos with a lower rating. As the track record of credit ratings during the last banking crisis was not that promising (Partnoy, 2009) supervisors might consider this fact as worrying. In the past years, banking regulation has limited the use of credit ratings in the credit risk framework. Nevertheless, the market still seems to assign significant importance to the opinion of rating agencies for lack of any better information.

A logical question then is whether ratings are a good predictor of the quality of CoCos. Not in this case: we also show that there was a very low correlation between the relevant ratings and the issuing banks' distance to the MDA trigger at the time of the DB scare. The results of our paper indicate strongly that downgrades did not keep up with actual developments. Given the past experience with credit ratings in the financial crisis and the delays in downgrades, it is 
questionable whether market reliance on ratings to the extent demonstrated in this paper is desirable. For the time being, there is a legitimate question whether Cocos, with all the uncertainties surrounding their actual operation in times of stress demonstrated in this paper, are actually a source of fragility, their positive impact on loss absorption capacity notwithstanding. Directions for future research

This study is an event study with a focus on the MDA-trigger and its role in the price response of CoCos to the DB turmoil of January/February 2016. To really assess the value of CoCo prices as bellwethers of risk one would need to look into the explanatory factors of CoCo-prices not just in response to one specific event but using a longer, dynamic panel data set. This would also allow assessment of the impact of design features of CoCos on CoCo prices.

2017 should be an interesting year for further research on CoCos and the informativeness of their prices because as of 2017 the Pillar 2 requirements will be disclosed to the market. This means that investors should be able to derive the height of the MDA-trigger themselves. Until 2017, banks have been strongly discouraged to publish the height of the Pillar 2 requirements some even through a formal letter from the supervisor. However, as the European Securities and Markets Authority considers the height of the MDA-trigger relevant information for investors in order to be able to properly judge the risks present in CoCos, market authorities will force banks to disclose the capital requirements that are MDA relevant. Due to this change in disclosure requirements, it would be interesting to verify whether markets are now better able to respond better to changes in the capital base versus the requirements. Future research could verify whether disclosure of capital requirements has an impact on CoCo-prices, and whether the fact that their value is now in the public domain makes market prices better reflect the risks embedded in these instruments. On the one hand, more transparency could indeed result in prices better reflecting risks in CoCos. On the other hand, the market could have done similar calculations in the past as well, by making an average estimation of Pillar 2 requirements, which do not differ that materially across big banks that issue CoCos.

\section{Open questions for Policy makers}

The outcomes of our research suggests that policy makers should closely monitor whether the market is able to better absorb available information about CoCos now that the MDA triggers are disclosed as of 2017. One question will be whether improving the information environment for CoCos has reduced spurious volatility and in particular will lead to less widespread and more discriminating market 
responses to new events. In addition policy makers should further investigate the trade-off between a low MDA trigger, which will possibly result in fewer negative market events with CoCos and a higher MDA trigger which would prevent banks in trouble to continue distributions as a way of signaling market strength but thereby decreasing their capital base. Acharya et al. (2016) show that the worst performing banks during the most recent stress tests, have distributed most dividends. Lowering the MDA-trigger, which mainly helps poorly performing banks, can help them to continue to pay-out coupons, whereas strengthening their capital base might be a better alternative.

Another issue of policy relevance is the role of CoCos in the regulatory framework. CoCos can now be used to meet Pillar 1 requirements and depending on the supervisor, also Pillar 2. If CoCos create more market turbulence than CET 1 capital, and the loss absorption benefits of CoCos do not fully outweigh the disadvantages, policy makers might need to consider a more limited role for CoCos in the regulatory framework. Another issue needing more scrutiny is the design of the MDA trigger. Should the MDA trigger design, as it is now, remain the same for dividends and bonuses as for coupon payments? Especially when the MDA trigger will be connected to the MREL/TLAC requirements, a different design for coupons, dividends and bonuses may be worth further investigating as this trigger is likely to be hit more frequently.

We think that the research reported on in this paper and the additional work waiting to be done is highly relevant for policy makers and market participants considering the issue and structure of new CoCos. Price discovery is one of the key functions of financial market, and we have demonstrated in this paper that the opaqueness surrounding the MDA trigger for Cocos is undermining that price discovery function, leading to information contagion triggering sudden panics and crashes that do not always seem to be in line with underlying fundamentals. 


\section{References}

Admati, R. DeMarzo, P.M., Hellwig, M.F., and P.C Pfleiderer (2013) "Fallacies, Irrelevant Facts, and Myths in the Discussion of Capital Regulation: Why Bank Equity is Not Socially Expensive." Stanford University Working Paper No. 2063.

Ahnert, Toni and C. Georg (2017), "Information Contagion and Systemic Risk", Journal of Financial Stability, https://doi.org/10.1016/j.jfs.2017.05.009

Anthony J.H., and K. Rames (1992). "Association between Accounting Performance Measures and Stock Prices." Journal of Accounting and Economics. pp. 203-227

AFM 2015, CoCo's niet geschikt voor meeste particuliere beleggers. https://www.afm.nl/nl-nl/professionals/nieuws/2015/mrt/cocos-particulierebeleggers

Albul, B., D. Jaffee and A. Tchistyi (2012): "Contingent Convertible Bonds and Capital Structure Decisions." University of California, Berkeley, Working Paper.

Acharya, V.V., Pierret, D., Steffen, S. "Capital Shortfalls of European Banks since the Start of the Banking Union Discussion and Working Paper.

Avdjiev S., A. Kartasheva, and B. Bogdanova (2013). CoCos: a Primer. BIS Quarterly Review, pp.43-56.

Avdjiev, S., P. Bolton, W. Jiang, K. Kartasheva, and B. Bogdanova (2015) "Coco bonds issuance and bank funding costs: An empirical analysis", BIS Working paper.

BCBS (2011): Basel III, A global regulatory framework for more resilient banks and banking systems. http://www.bis.org/publ/bcbs189.pdf

BCBS (2014): Basel III Leverage ratio framework and disclosure requirements.

Berger, A.N. (1995). "The Profit-Structure Relationship in Banking: Test of Market-Power and Efficient Structure Hypotheses." Journal of Money, Credit and Banking Vol. 27, pp 371-96

Black, L., R. Correa, X. Huang, and H. Zhou (2016). "The Systemic Risk of European Banks during the Financial and Sovereign debt crisis." Journal of Banking and Finance. Vol. 63, pp 107-125

Bloomberg, 2016. "Banks CoCo Coupon Payments made safer in new ECB Capital Regime" https://www.bloomberg.com/news/articles/2016-07-27/banks-coco-couponpayments-made-safer-in-new-ecb-capital-regime

Blundell-Wignall, A. (2010) "Thinking beyond Basel III: necessary solutions for capital and liquidity" OECD Journal: Financial Market Trends, Vol. 2010(1).

Boermans, M.and S. Van Wijnbergen (2017). "Contingent Convertible bonds: Who Invests in European CoCos?" Applied Economic Letters.

Calomiris, C. and R. Herring (2013) "How to Design a Contingent Convertible Debt Requirement that Helps to Solve out Too Big-to-Fail Problem" Journal of Applied Corporate Finance Vol. 25(2) pp. 39-62.

Chan, S. and S. van Wijnbergen (2014) "CoCos, Contagion and Systemic Risk". Tinbergen Institute Discussion Paper 110, CEPR DP 10960.

Chan, S. and S. van Wijnbergen (2016), "CoCo Design, Risk Shifting and Systemic Risk", CEPR Discussion Paper 11099.

Chan, S. and S. van Wijnbergen (2017), "Regulatory Forbearance, CoCos, and Bank RiskShifting", CEPR Discussion Paper no ***

Connolly, R., C. Strivers, and L. Sun, (2005) "Stock Market Uncertainty and Stock-Bond Return relationship" Journal of Financial and Quantitative Analysis. Vol. 40(1), pp. 161-194. 
de Spiegeleer, J., W. Schoutens, and C. Vanhulle (2014). The handbook of hybrid securities: convertible bonds, coco bonds, and bail-in. The Wiley finance series Chichester, United Kingdom.

DNB (2016), SREP manual: internal guidelines on SREP.

DNB (2016) Mission DNB http://www.dnb.nl/en/about-dnb/onze-missie/index.jsp

EBA, (2015), Opinion of the European Banking Authority on the Interaction of Pillar 1, Pillar 2 and combined Buffer Requirements and Restrictions on Distributions. https://www.eba.europa.eu/documents/10180/983359/EBA-Op-201524+Opinion+on+MDA.pdf

EBA, (2014). Guidelines on Common Procedures and Methodologies for the Supervisory Review and Evaluation Process (SREP) https://www.eba.europa.eu/regulation-andpolicy/supervisory-review-and-evaluation-srep-and-pillar-2.

Fama, E.F. and K.R. French (1993), "Common Risk Factors in the Returns on Stocks and Bonds" Journal of Financial Economics, Vol. 33(1) pp. 3-56.

Financial Times (2009a) "Stability concerns over CoCo bonds", November 5

Financial Times (2009b) "Report warns on CoCo bonds", November 10.

French K.R., M.N. Baily, J.Y. Campbell, J.H. Cochrane, D.W. Diamond, et al. (2010). The Squam Lake Report: Fixing the Financial System. Princeton University Press.

Flannery, M.J. (2005) "No Pain, No Gain? Effecting Market Discipline via Reverse Convertible Debentures," in H.S. Scott (ed.), Capital Adequacy Beyond Basel: Banking,

Flannery, M.J. (2009) "Stabilizing Large Financial Institutions with Contingent Capital Certificates", University of Florida Working Papers.

Flannery, M.J. (2014) "Contingent Capital Instruments for Large Financial institutions: A Review of the Literature" Annual Review of Financial Economics, Vol. 6, pp. 225-240.

Glesaon, K. Bright, S., Martinez, F., Taylor, C. "Europe's CoCos Provide a Lesson on Uncertainty", OFR Working Paper.

Grier, P. and S. Katz, (1976) "The Differential Effects of Bond Rating Changes on Industrial and Public Utility Bonds by Maturity." Journal of Business, Vol. 49, pp. 226-239.

Gorton, G. and R. Rosen (1995) "Corporate Control, Portfolio Choice and the Decline of Banking" Journal of Finance, Vol. 50(13), pp. 1377-1420.

Hand, J.R.M., R.W. Holthausen and R.W. Leftwich (1992) "The Effect of Bond Rating Agency Announcements on Bond and Stock prices" Journal of Finance, Vol 47(2), pp. 733-752.

Hannoun, H. (2010), The Basel III Capital Framework: a Decisive Breakthrough. https://www.bis.org/speeches/sp101125a.pdf

Harvard Law Review Association (1991). Distress-Contingent Convertible Bonds: A Proposed Solution to the Excess Debt Problem. Harvard Law Review, 104(8), pp. 1857187.

Hilscher, J. and A. Raviv (2014) "Bank Stability and Market Discipline: the Effect of Contingent Capital on Risk Taking and Default Probability" Journal of Corporate Finance. Vol. 29, pp. 542-560.

Hirtle, B.J and J.A. Lopez (1999) "Supervisory Information and the Frequency of Bank Examinations" Federal Reserve Bank of New York, Economic Policy Review Vol. 5, pp. 1-20.

Hirschhorn, E. (1987) "The Informational Content of Bank Examination Ratings." Federal Deposit Insurance Corporation, Banking and Economic Review pp. 6-11.

Hüser, A.-C., and G. Halaj, C. Kok, C. Perales, and A.F. van der Kraaij, (2017) The Systemic Implications of Bail-In: A Multi-Layered Network Approach. ECB Working Paper No. 2010. 
Jimenez, G., J. Lopez, and J.A., Saurina (2013). "How does Competition affect Bank RiskTaking?" Journal of Financial stability Vol. 9, pp. 185-195.

O'Keefe, J., and D. Dahl (1996) "The Scheduling and Reliability of Bank Examinations: The Effect of FDICIA" Paper presented to the Financial Management Association.

Koziol, C. and J. Lawrenz (2010). "Contingent Convertibles. Solving or Seeding the next Banking Crisis?" Journal of Banking and Finance. Vol. 36(1), pp. 90-104.

Kwan, S. and R.A. Eisenbeis (1997) "Bank Risk, Capitalization, and Operating Efficiency" Journal of Financial Services Research, Vol. 12(2), pp. 117-131.

Lev, B. (1974) "On the Association between Operating Leverage and Risk", Journal of Financial and Quantitative Analysis, Vol. 9, pp. 627-642.

Myers, S.C. and N. Majluf (1984) "Corporate Finance and Investment Decisions When Firms Have Information That Investors Do Not Have," Journal of Financial Economics, Vol. 5, pp. 187-221.

Nam, K., C.S. Pyun, and S.L. Avart (2001) "Asymmetric Reverting Behavior of ShortHorizon Stock Returns: Evidence of Stock Market Overreaction" Journal of Banking and Finance, Vol. 25, pp. 807-824.

Partnoy, F. (2009) "Overdependence on Credit Ratings was a Primary Cause of the Crisis" Legal Studies Research Paper Series, Vol. 9.

Pasiouras, F. and K. Kosmidou (2007) "Factors Influencing the Profitability of Domestic and Foreign Commercial Banks in the European Union" Research in International Business and Finance, pp. 222-237.

Pelizzon, L. and S. Schaefer (2005) "Pillar 1 vs Pillar 2 under Risk Management" The Risks of Financial Institutions, pp. 377-416.

Prescott, E.S. (2012) "Contingent Capital: The Trigger Problem", Federal Reserve Bank of Richmond Economic Quarterly. Vol. 98(1), pp. 33-50.

Standard and Poors (2014) Bank Hybrid Capital and Nondeferrable Subordinated Debt Methodology and Assumptions.

Squam Lake Working Group on Financial Regulation (2009). "An expedited Resolution Mechanism for Distressed Financial Firms: Regulatory Hybrid Securities. http://www.cfr.org/world/expedited-resolution-mechanism-distressed-financialfirms-regulatory-hybrid-securities/p19002

Stevens, N. and S. van Wijnbergen (2017), 'Contingent Convertibles put to the test: DB's profit warning and Contagion Effects', in process, University of Amstedam.

Sundaresan, S., and Z. Wang (2015) "On the Design of Contingent Capital with a Market Trigger." Journal of Finance, Vol. 70, pp. 881-920.

Wilkens, S. and N. Bethke (2014). "Contingent convertible (coco) bonds: A first empirical assessment of selected pricing models." Financial Analysts Journal, Vol. 70(2), pp. 59-72.

Zingales L. and O. Hart (2012) "A New Capital Regulation for Large Financial Institutions" American Law and Economics Review. 


\section{Appendix}

Glossary

AT1: Additional Tier 1 instruments. Contingent Convertibles or CoCos. Instruments that may be written down or converted when certain triggers are hit.

Combined Buffer Requirement (CBR) total of the buffer requirements applicable to bank. Consists of Capital Conservation Buffer, Counter Cyclical buffer and the Systemic Risk buffer.

MDA trigger: Maximum distributable amount trigger. The point at which banks will have to deal with automatic restrictions on coupons, bonuses and dividends.

MREL: Minimum requirement for own fund and eligible liabilities. Additional capital requirements for resolution purposes, which can be met with a lower qualify of capital (e.g. Tier 3).

Pillar 1 requirements Standard risk weighted capital requirements of banks $(8 \%)$

Pillar 2 requirements Idiosyncratic capital requirements based on risks not sufficiently covered under P1.

Stacking Order: The way in which capital requirements are stapled. E.g. $\mathrm{P} 1+\mathrm{P} 2+\mathrm{CBR}$.

Additional Tier 1

\begin{tabular}{|c|c|c|}
\hline Coupon & $\begin{array}{l}\text { Discretionary } \\
\text { Non-cumulative } \\
\text { Paid out of distributable items } \\
\text { Restricted if in breach of CBR } \\
\text { (MDA, art } 141 \text { CRD IV) }\end{array}$ & $\begin{array}{l}\text { Mandatory } \\
\text { Cumulative }\end{array}$ \\
\hline Maturity & $\begin{array}{l}\text { Perpetual } \\
\text { First issuer call: } \geq 5 \text { years with } \\
\text { regulatory approval, no incentive } \\
\text { to redeem }\end{array}$ & $\begin{array}{l}\text { Minimum } 5 \text { years } \\
\text { First issuer call: } \geq 5 \text { years } \\
\text { with regulatory approval, } \\
\text { no incentive to redeem }\end{array}$ \\
\hline $\begin{array}{l}\text { Early calls (prior to } \\
5 \text { years) }\end{array}$ & $\begin{array}{l}\text { Change in tax treatment } \\
\text { Change in regulatory treatment. } \\
\text { Only with regulatory approval }\end{array}$ & $\begin{array}{l}\text { Change in tax treatment } \\
\text { Change in regulatory } \\
\text { treatment } \\
\text { Only with regulatory } \\
\text { approval }\end{array}$ \\
\hline
\end{tabular}




\begin{tabular}{l|l|l}
\hline Ranking & $\begin{array}{l}\text { Above ordinary shares (CET1) } \\
\text { and Below Tier 2 }\end{array}$ & $\begin{array}{l}\text { Above Tier 1 } \\
\text { Below depositors and } \\
\text { senior creditors }\end{array}$ \\
\hline Events of default & $\begin{array}{l}\text { Non-payment (only if due) } \\
\text { Winding-up }\end{array}$ & $\begin{array}{l}\text { Non-payment } \\
\text { Winding-up }\end{array}$ \\
\hline $\begin{array}{l}\text { Regulatory } \\
\text { amortisation }\end{array}$ & N/A & $\begin{array}{l}\text { 20\% reduction in capital } \\
\text { recognition in each of 5 } \\
\text { final years to maturity }\end{array}$ \\
\hline $\begin{array}{l}\text { Loss absorption } \\
\text { going concern }\end{array}$ & $\begin{array}{l}\text { Write-down (permanent or } \\
\text { temporary) or conversion into } \\
\text { ordinary shares } \\
\text { Trigger: below 5.125\% CET1 }\end{array}$ & N/A \\
\hline $\begin{array}{l}\text { Loss absorption } \\
\text { gone concern }\end{array}$ & $\begin{array}{l}\text { Point of non-viability } \\
\text { Point of non-viability }\end{array}$ \\
\hline
\end{tabular}

CoCo-instruments used in the analyses

\begin{tabular}{|c|c|c|c|}
\hline DE000A1TNDK2 & AAREAL BANK AG & XS1055037177 & CREDIT AGRICOLE SA \\
\hline XS1278718686 & ABN AMRO BANK NV & US225313AJ46 & CREDIT AGRICOLE SA \\
\hline US01538RAE99 & ALFA BANK (ALFA BOND) & XS1055037920 & CREDIT AGRICOLE SA \\
\hline XS1328798779 & ALLIED IRISH BANKS PLC & US225313AD75 & CREDIT AGRICOLE SA \\
\hline BE6271761320 & AXA BANK EUROPE SA & US225313AE58 & CREDIT AGRICOLE SA \\
\hline XS0926832907 & BANCO BILBAO VIZCAYA ARG & US225313AC92 & CREDIT AGRICOLE SA \\
\hline XS1033661866 & BANCO BILBAO VIZCAYA ARG & XS1044578273 & DANSKE BANK A/S \\
\hline XS1190663952 & BANCO BILBAO VIZCAYA ARG & XS1190987427 & DANSKE BANK A/S \\
\hline XS0979444402 & BANCO POPULAR ESPANOL SA & DE000DB7XHP3 & DEUTSCHE BANK AG \\
\hline XS1189104356 & BANCO POPULAR ESPANOL SA & US251525AN16 & DEUTSCHE BANK AG \\
\hline XS1043535092 & BANCO SANTANDER SA & XS1071551474 & DEUTSCHE BANK AG \\
\hline XS1066553329 & BANCO SANTANDER SA & XS1071551391 & DEUTSCHE BANK AG \\
\hline XS1107291541 & BANCO SANTANDER SA & XS1207306652 & DNB BANK ASA \\
\hline XS0862044798 & BANK OF IRELAND & N00010730708 & DNB BANK ASA \\
\hline DK0030278643 & BANKNORDIK P/F & DE000DG0AT11 & DZ BANK AG \\
\hline US06740L8C27 & BARCLAYS BANK PLC & DE000DG0AT29 & DZ BANK AG \\
\hline US06739FHK03 & BARCLAYS BANK PLC & DE000DG0AT52 & DZ BANK AG \\
\hline US06738EAA38 & BARCLAYS PLC & DE000DG0AT37 & DZ BANK AG \\
\hline US06738EAB11 & BARCLAYS PLC & XS1248345461 & Bank of Ireland \\
\hline XS1002801758 & BARCLAYS PLC & US404280AT69 & HSBC HOLDINGS PLC \\
\hline XS1274156097 & BARCLAYS PLC & US404280AR04 & HSBC HOLDINGS PLC \\
\hline XS1068574828 & BARCLAYS PLC & XS1111123987 & HSBC HOLDINGS PLC \\
\hline XS1068561098 & BARCLAYS PLC & US404280AS86 & HSBC HOLDINGS PLC \\
\hline XS1247508903 & BNP PARIBAS & XS1298431104 & HSBC HOLDINGS PLC \\
\hline US05565AAN37 & BNP PARIBAS & US456837AE31 & ING GROEP NV \\
\hline XS1171914515 & COOPERATIEVE RABOBANK UA & US456837AF06 & ING GROEP NV \\
\hline XS0583302996 & COOPERATIEVE RABOBANK UA & XS1346815787 & INTESA SANPAOLO SPA \\
\hline XS0703303262 & COOPERATIEVE RABOBANK UA & US46115HAU14 & INTESA SANPAOLO SPA \\
\hline XS0496281618 & COOPERATIEVE RABOBANK UA & XS0545782020 & INTESA SANPAOLO SPA \\
\hline
\end{tabular}




$\begin{array}{ll}\text { BE6248510610 } & \text { KBC BANK NV } \\ \text { BE0002463389 } & \text { KBC GROEP NV } \\ \text { XS1202090947 } & \text { NORDEA BANK AB } \\ \text { XS1202091325 } & \text { NORDEA BANK AB } \\ \text { US65557CAM55 } & \text { NORDEA BANK AB } \\ \text { US65557CAN39 } & \text { NORDEA BANK AB } \\ \text { XS1202091671 } & \text { NORDEA BANK AB } \\ \text { XS1227057814 } & \text { PERMANENT TSB PLC } \\ \text { CH0272748754 } & \text { RAIFFEISEN SCHWEIZ } \\ \text { CH0210638497 } & \text { RAIFFEISEN SCHWEIZ } \\ \text { XS1244538523 } & \text { SANTANDER UK GROUP HLDGS } \\ \text { US78406JAE47 } & \text { SBERBANK (SB CAP SA) } \\ \text { US78406JAD63 } & \text { SBERBANK (SB CAP SA) } \\ \text { XS0867620725 } & \text { SOCIETE GENERALE } \\ \text { XS0867614595 } & \text { SOCIETE GENERALE } \\ \text { US83368JFA34 } & \text { SOCIETE GENERALE }\end{array}$

US83367TBF57 SOCIETE GENERALE

US83367TBH14 SOCIETE GENERALE

CH0214139930 UBS AG

CH0244100266 UBS AG

CH0236733827 UBS AG

XS0747231362 UBS AG JERSEY BRANCH

US90261AAB89 UBS AG STAMFORD CT

CH0286864027 UBS GROUP AG

CH0271428317 UBS GROUP AG

CH0271428333 UBS GROUP AG

CH0271428309 UBS GROUP AG

XS1107890847 UNICREDIT SPA

XS1046224884 UNICREDIT SPA

XS0527624059 UNICREDIT SPA

CH0248531110 VTB BANK (VTB CAPITAL SA) 